\title{
Prevalence of Sub-clinical Mastitis in Dairy Cow of Rewa District of Madhya Pradesh
}

\author{
Komal Singh ${ }^{1}$, Krishan Kumar Mishra ${ }^{1}$, Neeraj Shrivastava ${ }^{2}$, Amit Kumar Jha $^{3}$ and Rajeev Ranjan ${ }^{4 *}$ \\ ${ }^{1}$ Department of Veterinary Medicine, College of Veterinary Science E A.H., Rewa, Nanaji Deshmukh Veterinary Science \\ University, Madhya Pradesh, INDIA \\ ${ }^{2}$ Department of Veterinary Microbiology, College of Veterinary Science E A.H., Rewa, Nanaji Deshmukh Veterinary Science \\ University, Madhya Pradesh, INDIA \\ ${ }^{3}$ Department of Animal Genetics \& Breeding, College of Veterinary Science E A.H., Rewa, Nanaji Deshmukh Veterinary Science \\ University, Madhya Pradesh, INDIA \\ ${ }^{4}$ Department of Veterinary Pharmacology \& Toxicology, College of Veterinary Science \& A.H., Rewa, Nanaji Deshmukh \\ Veterinary Science University, Madhya Pradesh, INDIA \\ "Corresponding author: R Ranjan; E-mail: rajeev2049@gmail.com
}

Received: 4 Dec., 2020

Revised: 05 Jan., 2021

Accepted: 13 Jan., 2021

\begin{abstract}
Among myriads of factors causing huge loss to the dairy industry, mastitis occupies major cause of concern. Sub-clinical mastitis (SCM) is an inflammation of udder without any visible changes in the udder and milk. In this study, 242 no. of cows were screened by modified California Mastitis Test (mCMT), milk pH, electrical resistance (ER) and somatic cell count (SCC). Apparently healthy cows had the mean value of milk pH, ER, and SCC was $6.57 \pm 0.04,356.67 \pm 13.33$ and $1.52 \pm 0.12 \times 105$ cells/ $\mathrm{ml}$, respectively, while the corresponding values in SCM infected cows were 7.55 $\pm 0.04,315.00 \pm 19.45$ and $17.22 \pm 3.12 \times 105$ cells $/ \mathrm{ml}$. The overall prevalence of SCM infected cow was found to be $31.40 \%$ on animal wise, $7.85 \%$ on quarter wise, and $2.48 \%$ on blind teat wise. The individual quarter wise prevalence was found to be highest in left hind quarter $(15.70 \%)$ and left fore quarter (5.78\%), while lowest in right hind quarter (5.37\%) and right fore quarter (4.54\%). The prevalence of SCM in relation to stage of lactation in cows revealed highest (36.54\%) in early stage of lactation followed by late (34.38\%) and mid $(27.78 \%)$ stages of lactation. The variable prevalence of SCM was observed at different stage of parity. The highest prevalence was observed at $2^{\text {nd }}$ parity $(66.67 \%)$ followed by $1^{\text {st }}$ parity $(43.33 \%), 4^{\text {th }}$ parity $(40.75 \%), 3^{\text {rd }}$ parity $(30.00 \%), 5^{\text {th }}$ parity $(19.44 \%)$, $6^{\text {th }}$ parity $(13.04 \%)$ and lowest at $7^{\text {th }}$ and above parity $(8.57 \%)$. Losses incurred due to mastitis can be minimized by improving management and milking practices.
\end{abstract}

\section{HIGHLIGHTS}

(0) The SCM is asymptomatic in nature.

(0 The mean value of milk $\mathrm{pH}, \mathrm{ER}$, and SCC was significantly changed in SCM.

0 The overall prevalence of SCM in cows was reported to be $31.40 \%$.

(0 It must be mandatory to screen the infected cow at regular interval to prevent the SCM

Keywords: Prevalence, Sub-clinical mastitis, modified California Mastitis Test, Quarter, Parity, Cow

Mastitis can be either clinical (CM) or sub-clinical (SCM). The both CM and SCM are inflammatory conditions of the mammary gland that are accompanied by physicochemical alterations in milk along with pathological changes in the mammary gland (Constable et al., 2017). In the clinical mastitis, visible changes in milk (colour, consistency, clots and decreased production) are being associated with changes in udder (swelling, heat, redness and pain) along with an abnormal gland or systemic changes, such as

How to cite this article: Singh, K., Mishra, K.K., Shrivastava, N., Jha, A.K. and Ranjan, R. (2021). Prevalence of sub-clinical mastitis in dairy cow of Rewa district of Madhya Pradesh. J. Anim. Res., 11(1): 89-95. Source of Support: None; Conflict of Interest: None 
pyrexia and inappetence, may also be present depending on the severity of the inflammation (Fox, 2009).

The SCM is asymptomatic without any local and systemic changes and it is most common in dairy cattle than clinical mastitis (Abebe et al., 2016). In SCM, milk from quarters appears normal, and the presence of inflammation can only be detected using laboratory tests. SCM is most commonly caused due to an existing or recent infection of the mammary gland with a microorganism (Djabri et al., 2002). The SCM can be detected in milk by modified California Mastitis Test (mCMT), Somatic Cell Count (SCC), Electrical Resistance (ER), and milk pH (Lafi, 2006). The mCMT is considered as most accurate test than other tests for field diagnosis of SCM (Lahamge et al., 2019).

Besides causing huge economic losses to milk production, the SCM affected animals remain a continuous source of infection to other herd mates. The prevalence of SCM in dairy cattle may develop clinical mastitis at any time under certain stress, managemental, environmental, animal's related factors. Early diagnosis of SCM is essential because changes in the udder tissue take place much earlier than they become apparent. It could reduce the production cost as well as to take necessary action to prevent clinical mastitis.

Literature available on the magnitude of SCM and its risk factors is very scanty in Rewa District of Madhya Pradesh (India). Especially, no study has been taken up to investigate SCM. In view of the above, the present study was taken up to determine the prevalence of bovine SCM in dairy cattle and to determine the associated risk factors in the study area.

\section{MATERIALS AND METHODS}

\section{Study area}

The study was conducted in urban, peri urban and rural areas (Instructional Dairy Farm, Laxman Bag Gaushala, Mahajantola Farm, Kamdhenu Dairy Farm, Kuthulia, Bichhiya, Maidani, Silpara, Amilki, Gangapur, Govindgarh etc) of Rewa district of Madhya Pradesh (India) located between $24^{\circ} 18^{\prime}$ and $25^{\circ} 12^{\prime}$ 'north latitudes and $81^{\circ} 2^{\prime}$ ' and $82^{\circ} 18^{\prime}$. Land area of Rewa district is $6,240 \mathrm{~km}^{2}$. It has a humid subtropical climate, with cold, misty winters, hot summer and a humid monsoon season. This district has been naturally bestowed with immensely rich domestic livestock diversity. Livestock provides livelihood to the rural community and this also provide employment for the people in this region.

\section{Epidemiological Studies}

Epidemiology of SCM in cattle was studied in lactating dairy cows of different risk factor. The standard questionnaire was prepared to collect the information from the organized/ unorganized farms/village taking different parameters, about individual animals, breed of cattle, age, lactation number (parity), season and breed. The milk samples were collected from 944 quarters of 242 cows during June 2018 to July 2019.

\section{Clinical examination of the udder/milk}

The dairy farms were physically inspected for cleanness, handling, milking procedures and other factors associated with mastitis. The udder and every individual teat was examined clinically, using visual and through manual palpation. The glands were palpated for indurations and asymmetry. Teat ends were observed for alterations such as scars, wounds, patent teat orifice and ease of milking. The udder was also examined to ascertain the abnormality in the form of inflammatory swelling, fibrosis etc. Milk was grossly examined for discoloration, clots or flakes, pus, blood staining and consistency (Quinn et al., 2002).

\section{Detection of mastitis}

Modified California Mastitis Test (mCMT) was used for screening of lactating dairy cattle as cow side test on the spot to confirm the positive SCM milk samples. In brief mCMT, a plastic paddle with four chambers or shallow cups was used to perform this test. About $3 \mathrm{ml}$ of milk was directly striped into the labeled cups as Left Fore (LF), Left Hind (LH), Right Fore (RF) and Right Hind (RH), from the respective four quarters. Then approximately equal quantity of the test reagent (3\% Sodium Lauryl Sulphate/ CMT reagent) was added to each cup. The mixture of the milk and reagent was shaken gently in a rotating manner of the paddle in the horizontal plane. The paddle cups 
contained milk and reagent was rotated for 10 seconds and results were recorded. For the interpretation of severity of mastitis, different scoring system for mCMT was considered during present study. Based on the thickness of the gel formed by $\mathrm{mCMT}$ reagent-milk mixture, test results were scored as 0 (negative), + trace ++ (weak positive), +++ (distinct positive) and ++++ (strong positive) (David et al., 2005; Sharma et al., 2018).

\section{Collection of milk samples}

The milk sample was collected from each teat of cow indicating $\mathrm{mCMT}$ positive for SCM. The udder and teats were cleaned and washed with potassium permanganate $0.01 \%$ then wiped with clean cloth. First few streams of foremilk was discarded and then about $25 \mathrm{ml}$ of milk from each affected quarter was collected in fresh, sterile, labeled screw cap test tubes and brought to the laboratory for further examination.

\section{Testing of milk samples}

\section{Milk pH}

Milk $\mathrm{pH}$ is increased in lactating dairy cattle with SCM and intra-mammary infection. Milk $\mathrm{pH}$ testing provides an accurate, low-cost, and practical on-farm method for diagnosing SCM and intra-mammary infection (Constable et al., 2019; Kandeel et al., 2019). The estimation of the $\mathrm{pH}$ was done by the digital $\mathrm{pH}$ meter by dipping the bulb of $\mathrm{pH}$ meter in the milk sample and records the data of screen.

\section{Electrical Resistance (ER)}

Draminski Mastitis detector measures the changes in the electrical resistance of milk to detect SCM accompanied by an increase in salt levels in milk, which involves a change in the resistance. In brief, a minimum of $15 \mathrm{ml}$ of the first portion of milk was poured directly from the teat to measuring cup and the switch on button was pressed to read the result in units (Siddique et al., 2013; Galfi et al., 2015).

\section{Somatic Cell Count (SCC)}

The SCC was most accurate test for the diagnosis of SCM (Sharma et al., 2008; Sharma and Pandey, 2011). In brief, milk sample was thoroughly mixed, so as to obtain uniform distribution of cells. Four, one square $\mathrm{cm}$ areas were calibrated on grease free glass slide to make four milk smears $(0.01 \mathrm{ml}$ milk for each smear) with the help of a platinum loop. Slides were immersed for 20 seconds in Newman - Lampert stain. The leukocyte count in the SCM milk was performed to assess the degree of infection using Newman's stain as per the procedure described by Schalm et al. (1971) and Harmon (2001).

\section{Calculation}

The prevalence was expressed in percent positive by using the following formula:

$$
\text { Prevalence }=\frac{\text { No. of animals positive }}{\text { No. of animals tested }} \times 100
$$

\section{STATISTICAL ANALYSIS}

Data collected through questionnaire were analyzed using descriptive statistics of statistical software SPSS version 16.0 .

\section{RESULTS AND DISCUSSION}

\section{Milk profile of healthy and SCM infected cows}

In the present study, cows were screened by mCMT, milk $\mathrm{pH}, \mathrm{ER}$ and SCC. The mean value of milk $\mathrm{pH}, \mathrm{ER}$ and SCC was $6.57 \pm 0.04,356.67 \pm 13.33$ and $1.52 \pm 0.12 \times 105$ cells $/ \mathrm{ml}$, respectively in apparently healthy cows, while the corresponding values changed significantly $(\mathrm{p}<0.05)$ with $7.55 \pm 0.04,315.00 \pm 19.45$ and $17.22 \pm 3.12 \times 105$ cells/ml SCM infected cow (Table 1). These findings are close in accordance with the results of Ogola et al. (2007), Galfi et al. (2015), Panchal et al. (2016) and Mourya et al. (2020).

Table 1: Milk profile of healthy and SCM infected dairy cows

\begin{tabular}{lll}
\hline $\begin{array}{l}\text { Testing of milk } \\
\text { samples }\end{array}$ & $\begin{array}{l}\text { Healthy cows } \\
(\mathbf{n}=10)\end{array}$ & $\begin{array}{l}\text { SCM infected cows } \\
(\mathbf{n}=\mathbf{7 6})\end{array}$ \\
\hline $\mathrm{pH}$ & $6.57 \pm 0.04^{\mathrm{a}}$ & $7.55 \pm 0.04^{\mathrm{b}}$ \\
$\mathrm{ER}$ & $356.67 \pm 13.33^{\mathrm{a}}$ & $315.00 \pm 19.45^{\mathrm{b}}$ \\
$\mathrm{SCC}\left(10^{5}\right.$ cells $\left./ \mathrm{ml}\right)$ & $1.52 \pm 0.12^{\mathrm{a}}$ & $17.22 \pm 3.12^{\mathrm{b}}$ \\
mCMT score & Negative & $+/++/+++/++++$ \\
\hline
\end{tabular}

*Values bearing different superscript differ significantly in row $(\mathrm{p}<0.05)$. 


\section{The overall prevalence of SCM}

The present study was conducted on a total of 242 milking cows, out of these 76 lactating cows were mCMT positive. The overall prevalence of SCM was found to be $31.40 \%$ on the basis of animal (Table 2). These findings are in close agreements with the reports of Maheshwari et al. (2016), Swami et al. (2017), Constable et al. (2019) and Shaikh et al. (2019) who have recorded prevalence of SCM to be $27.81 \%, 35.00 \%, 31.21 \%$ and $33 \%$, respectively. However, higher prevalence was reported by Mir et al. (2014), Mekonnen et al. (2017) and Ndahetuye et al. (2019) as $57.80 \%, 37.20 \%, 62.00 \%$, and $76.25 \%$, respectively. Sharma et al. (2018) also recorded SCM occurrence rate to be higher at unorganized farms $(65.08 \%)$ than at organized ones $(51.82 \%)$ in the of Jammu region of J \& K.

Table 2: The overall prevalence of SCM in dairy cows

\begin{tabular}{llll}
\hline Particulars & $\begin{array}{l}\text { Total no. of Cow/ } \\
\text { Quarter/Teat } \\
\text { screened }\end{array}$ & $\begin{array}{l}\text { No. of CMT } \\
\text { positive Cow/ } \\
\text { Quarter/Blind } \\
\text { Teat }\end{array}$ & $\begin{array}{l}\text { Prevalence } \\
(\%)\end{array}$ \\
\hline Cows & 242 Cows & 76 Cows & 31.40 \\
Quarters & 968 Quarters & 76 Quarters & 7.85 \\
Teat & 944 Teats & 76 Teats & 8.05 \\
Blind Teats & 968 Teats & 24 Blind Teats & 2.48 \\
\hline
\end{tabular}

A total of 76 quarters from 968 quarters were positive to $\mathrm{mCMT}$. The overall quarter wise prevalence of SCM was $7.85 \%$ (Table 2). There was a variation of mCMT score even in different quarters of individual lactating cow. The higher prevalence of $23.00 \%$ and $31.55 \%$ was reported by Patel and Trivedi (2015) and Mourya et al. (2020), respectively in the infected quarters of cows. Most important concern was about $2.48 \%$ of permanent functional loss of teats (blind teats) in cows (Table 2). Sharma et al. (2018) have recorded $9.00 \%$ blind teats in cows. Hence, the variation in prevalence of SCM in different studies may be attributed to various risk factors responsible for development of mastitis. These factors are present at both cow and quarter level. It might be due to the fact that the farmers could not maintain proper hygiene at dairy farm due to non-scientific rearing of animals. Ergun et al. (2004) stated factors like herd size, milking method practice, agro climatic conditions of the region, variations in socio-cultural practices, milk marketing, literacy level of the animal owner and feeding practices were affecting the prevalence of SCM.

\section{Individual quarter wise prevalence}

On quarter basis prevalence of SCM in cows, hind quarters $(10.54 \%)$ were mostly affected as compared to fore quarters $(5.17 \%)$. In addition, the individual quarter wise prevalence was found to be highest in left hind quarter $(15.70 \%)$ followed by left fore quarter $(5.78 \%)$, right hind quarter $(5.37 \%)$ and right fore quarter $(4.54 \%)$ (Table 3). Mourya et al. (2020) reported the highest prevalence $22.14 \%$ in right fore quarter followed by $21.08 \%$ in right hind quarter, $19.32 \%$ in left fore quarter and the lowest prevalence of $18.18 \%$ in left hind quarter of cattle with SCM. Qadri (2015) and Maheshwari et al. (2016) also reported higher prevalence of $11.23 \%$, $9.03 \%$, and $32.25 \%, 27.25 \%$ in right and left side quarters, respectively. While, Srinivasan et al. (2013) reported the quarter-wise prevalence in left fore, left hind, right fore and right hind quarters to be $11.11 \%, 46.30 \%, 5.50 \%$ and $37.04 \%$, respectively. Singh et al. (2010) opined that the incidence of SCM occurs higher in hind quarters as compared to fore quarters and this could be attributed to greater exposure of the hind quarters to contamination with dung and urine. This might be due to the fact that hind quarters are highly prone to contamination with dirty and large amount of milk is produced from hindquarters and as a result, the pressure on teat canal forces the canals to be opened widely, which allow entrance of microbes. Akhtar et al. (2012) added that more involvement of hind quarters might be due to more frequent exposure to dung and urine, large capacity and mass, greater vulnerability to direct trauma and relatively more closeness to the floor as compared to fore quarters.

Table 3: Individual quarter wise prevalence of SCM in dairy cows

\begin{tabular}{lllll}
\hline $\begin{array}{l}\text { Quarter's } \\
\text { position }\end{array}$ & $\begin{array}{l}\text { Position of } \\
\text { teat }\end{array}$ & $\begin{array}{l}\text { No. of } \\
\text { quarter } \\
\text { screened }\end{array}$ & $\begin{array}{l}\text { No. of } \\
\text { quarter } \\
\text { positive }\end{array}$ & $\begin{array}{l}\text { Prevalence } \\
\text { (\%) }\end{array}$ \\
\hline \multirow{4}{*}{ Fore } & Right & 242 & 11 & 4.54 \\
& Left & 242 & 14 & 5.78 \\
& Total & 484 & 25 & 5.17 \\
\hline \multirow{4}{*}{ Hind } & Right & 242 & 13 & 5.37 \\
& Left & 242 & 38 & 15.70 \\
& Total & 484 & 51 & 10.54 \\
\hline
\end{tabular}




\section{Lactation stage wise prevalence}

The lactation stage was divided into early lactation (1 to 3 months), mid lactation ( 3 to 6 months) and late lactation (6 months onwards) till drying off. The prevalence of SCM in relation to stage of lactation in cattle revealed highest (36.54\%) in early stage of lactation followed by late stage of lactation (34.38\%) and mid stages of lactation (27.78\%) (Table 4). This observation supports the findings of Pal and Verma (1991), Islam et al. (2011) and Maheshwari et al. (2016). The high rate of SCM during the early stage of lactation may be due to the fact that high yielding cattle with enlarged status of udder are highly prone to infection and inflammatory process. The higher incidence of SCM is more common in early lactation phase which could be due to physiological stress of lactation and alterations in homeostasis mechanisms (Rassol et al., 1985). In contrast, higher prevalence of SCM in late stage of lactation was recorded by Islam et al. (2019) and Sinha et al. (2011) in Bangladesh. Sharma et al. (2011) reported that dairy cows seemed to have more oxidative stress and low antioxidant defense during early lactation or just after parturition than advanced pregnant and this appears to be the reason for their increased susceptibility to production diseases and other health problems.

Table 4: Lactation stage wise prevalence of SCM in dairy cows

\begin{tabular}{llll}
\hline Lactation stage & $\begin{array}{l}\text { No. of cow } \\
\text { screened }\end{array}$ & $\begin{array}{l}\text { No. of cow } \\
\text { positive }\end{array}$ & $\begin{array}{l}\text { Prevalence } \\
\text { (\%) }\end{array}$ \\
\hline Early (1-3 month) & 52 & 19 & 36.54 \\
Mid (3-6 month) & 126 & 35 & 27.78 \\
Late (>6 month) & 64 & 22 & 34.38 \\
\hline
\end{tabular}

\section{Parity wise prevalence of SCM}

The status of SCM in cow having different lactation numbers ranging from $1^{\text {st }}$ to $7^{\text {th }}$ and more parity numbers was observed. The variable prevalence of SCM was observed at different parity. The highest prevalence was $66.67 \%$ in $2^{\text {nd }}$ parity, followed by $43.33 \%$ in $1^{\text {st }}$ parity, $40.75 \%$ in $4^{\text {th }}$ parity, $19.44 \%$ in $5^{\text {th }}$ parity, $13.04 \%$ in $5^{\text {th }}$ parity and lowest $(8.57 \%)$ in $7^{\text {th }}$ and above lactation (Table 4). Similar findings of higher prevalence of SCM in $2^{\text {nd }}$ parity were recorded by Nauriyal and Verma (2009) in cattle. Whereas, higher prevalence in $4^{\text {th }}$ parity were recorded by Islam et al. (2011), Maheshwari et al. (2016) and Mourya et al. (2020). The highest prevalence of SCM was found in $3^{\text {rd }}$ parity by Sinha et al. (2011) and Bhuiyan et al. (2020). This observation also supported the reports of Rasool et al. (1985) and Devi et al. (1997) who reported an increasing incidence of SCM with advancing age (parity) and lactations.

Tiwari et al. (2008) opined that incidence of mastitis increases as the lactation progresses and it attains a highest proportion during third and fourth lactation when the cows produce more milk and the udder becomes pendulous and more prone to infection. In addition, the increased prevalence of SCM in pleuriparous lactating cows might be due to increase in teat patency and frequency of previous exposure (Ayano et al., 2013). It has been proposed that incidence of infected quarter increases with the age and parities (Sharma et al., 2007; Sharma and Maiti, 2010). Multiple studies have also indicated that increasing parity increased the risk of mastitis in cows (Tiwari et al., 2008; Tufani et al., 2012).

Table 5: Parity wise prevalence of SCM in dairy cows

\begin{tabular}{llll}
\hline Parity & $\begin{array}{l}\text { No. of cow } \\
\text { screened }\end{array}$ & $\begin{array}{l}\text { No. of cow } \\
\text { positive }\end{array}$ & $\begin{array}{l}\text { Prevalence } \\
(\%)\end{array}$ \\
\hline $1^{\text {st }}$ & 30 & 13 & 43.33 \\
$2^{\text {nd }}$ & 24 & 16 & 66.67 \\
$3^{\text {rd }}$ & 40 & 12 & 30.00 \\
$4^{\text {th }}$ & 54 & 22 & 40.74 \\
$5^{\text {th }}$ & 36 & 7 & 19.44 \\
$6^{\text {th }}$ & 23 & 3 & 13.04 \\
$7^{\text {th }}$ and above & 35 & 3 & 8.57 \\
\hline
\end{tabular}

\section{CONCLUSION}

The present study was carried out to observe the prevalence of SCM on the basis of mCMT, SCC, ER and milk pH. The overall prevalence of SCM infected cow was found to be $31.40 \%$ on animal wise, $7.85 \%$ on quarter wise and $2.48 \%$ on blind teat wise. The individual quarter wise prevalence was found to be highest in left hind quarter (15.70\%) and left fore quarter $(5.78 \%)$. The highest prevalence of SCM seen in early stage of lactation $(36.54 \%)$, followed by late stage of lactation $(34.38 \%)$ and mid stages of lactation $(27.78 \%)$. The variable prevalence of SCM was observed at different stage of parity ( $43.33 \%$ on 1 st parity, $66.67 \%$ on $2^{\text {nd }}$ parity, $30.00 \%$ on $3^{\text {rd }}$ parity, $40.75 \%$ on $4^{\text {th }}$ parity, 
$13.04 \%$ on $5^{\text {th }}$ parity and $8.57 \%$ on $7^{\text {th }}$ and above parity). Considering the results of the current investigation, it is concluded that SCM is directly associated with individual animal, position of individual quarter, stage of lactation and stage of parity. The present study specifies that these factors play a major role in SCM. Therefore, it is mandatory to screen the infected cases at regular interval.

\section{ACKNOWLEDGMENTS}

The authors are grateful to College of Veterinary Science \& A.H., Rewa (Nanaji Deshmukh Veterinary Science University, Jabalpur, Madhya Pradesh, India) for providing necessary facilities to carry out the present investigation.

\section{REFERENCES}

Abebe, R., Hatiya, H., Abera, M., Megersa, B. and Asmare, K. 2016. Bovine mastitis: prevalence, risk factors and isolation of Staphylococcus aureus in dairy herds at Hawassa milk shed, South Ethiopia. BMC Vet. Res., 12: 270.

Akhtar, A., Habibulla, A.M. and Hidayatullah, A.M. 2012. Prevalence of sub-clinical mastitis in buffaloes in district Dera Ismail Khan. Pak. J. Pl. Sci., 64: 159-160.

Ayano, A.A., Hiriko, F., Simyalew, M. and Yohannes, A. 2013. Prevalence of sub-clinical mastitis in lactating cows selected commercial dairy farms of Holeta district. J. Vet. Med. Anim. Health, 5: 67-72.

Bansal, B.K. and Gupta, D.K. 2009. Economic analysis of bovine mastitis in India and Punjab: A review. Indian J. Dairy Sci., 67: 337-345.

Bhuiyan, M.U., Shahadat, H.M., Chakma, S.S., Islam, F., Islam, R., Islam, T. and Mahfuz, S. 2020. Prevalence of subclinical mastitis of dairy cows in Bijoynagar Upazila under Brahmanbaria District of Bangladesh. Adv. Anim. Vet. Sci., 8(4): 364-369.

Constable, P.D., Ebeid, M.H., Megahed, A.A. and Kandeel, S.A. 2019. Ability of milk $\mathrm{pH}$ to predict sub-clinical mastitis and intramammary infection in quarters from lactating dairy cattle. J. Dairy Sci., 102(2): 1417-1427.

Constable, P.D., Hinchcliff, K.W., Done, S.H. and Grunberg, W. 2017. Diseases of mammary gland, In: Veterinary Medicine. $11^{\text {th }}$ edn, Elseveir Ltd. St. Louis, Missouri, pp. 1904-2001.

David, W., Michael, W., Alvin, L., Rod, C. and Graeme, M.
2005. Chemical and rheological aspects of gel formation in the California Mastitis Test. J. Dairy Res., 72: 115-121.

Devi, B.K., Shukla, P.C. and Bagherwal, R.K. 1997. Incidence of sub-clinical mastitis in cows. Ind. J. Dairy Sci., 50: 477 478 .

Djabri, B., Bareille, N., Beaudeau, F. and Seegers. H. 2002. Quarter milk somatic cell count in infected dairy cows: a meta-analysis. Vet. Res., 33: 335-357.

Ergun, Y., Aslantas, O., Dogruer, G. and Cantekin, Z. 2004. Epidemiology of sub-clinical mastitis in small size dairy farms in Hatay region. Vet. Bilim. Derg., 20(4): 25-28.

Fox, L.K. 2009. Prevalence, incidence and risk factors of heifer mastitis. Vet. Microbiol., 134: 82-88.

Galfi, A., Radinovic, M., Milanov, D., Bobos, S., Pajic, M., Savic, S. and Davidov, I. 2015. Electrical conductivity of milk and bacteriological findings in cows with sub-clinical mastitis. Biotechnol. Anim. Husb., 31(4): 533-541.

Harmon, R.J. 2001. Somatic cell counts: A primer. In: Proc. National Mastitis Council Annual Meeting, pp. 3-9.

Islam, M.A., Islam, M.Z., Islam, M.A., Rahman, M.S. and Islam, M.T. 2011. Prevalence of sub-clinical mastitis in dairy cows in selected areas of Bangladesh. Bangladesh J. Vet. Med., 9(1): 73-78.

Islam, S., Barua, S.R., Islam, A., Moni, S.P., Uddin, H., Ferdous, J., Rahman, M.K., Hassan, M.M., Rahman, A. and Chawdhury, S. 2019. Epidemiology of sub-clinical mastitis in dairy cows in urban areas of chittagong, Bangladesh. Turk. J. Agric. Food Sci. Technol., 7: 845-850.

Kandeel, S.A., Megahed, A.A., Ebeid, M.H. and Constable, P.D. 2019. Ability of milk $\mathrm{pH}$ to predict sub-clinical mastitis and intramammary infection in quarters from lactating dairy cattle. J. Dairy Sci., 102: 1417-1427.

Lafi, S.Q. 2006. Use of Somatic Cell Count and California Mastitis test results from udder halves milk samples to detect sub-clinical intramammary infection in Awassi sheep. Small Rumin. Res., 62: 83-86.

Lahamge, M.S., Thakre, A., Bonde, S.W., Borkar, S.D., Somkuwar, A.P. and Patil, D.V. 2019. Prevalence of subclinical mastitis in cows: In and around Nagpur region. Int. J. Curr. Microbiol. App. Sci., 8: 83-88.

Maheshwari, P., Shukla, P.C., Rao, M.L.V. and Shukla, S.N. 2016. Occurrence of sub-clinical mastitis in cattle in and around Jabalpur, Madhya Pradesh. Haryana Vet., 55(2): 160162 .

Mekonnen, S.A., Koop, G., Melkie, S.T., Getahun, C.D., Hogeveen, H. and Lam, T.J.G.M. 2017. Prevalence of subclinical mastitis and associated risk factors at cow and herd level in dairy farms in North-West Ethiopia. Prev. Vet. Med., 145: 23-31. 
Mir, A.Q., Bansal, B.K. and Gupta, D.K. 2014. Sub-clinical mastitis in machine milked dairy farms in Punjab: prevalence, distribution of bacteria and current antibiogram. Vet. World, 7: 291-294.

Mourya, A., Shukla, P.C., Gupta, D.K., Sharma, R.K., Nayak, A., Singh, B., Jain, A. and Pradhan, S. 2020. Prevalence of sub-clinical mastitis in Cows in and around Jabalpur, Madhya Pradesh. J. Entomol. Zool. Stud., 8(4): 40-44.

Nauriyal, D.S. and Verma, A.K. 2009. Prevalence and bacterial spectrum of sub-clinical intramammary infection (IMI) in purebred Kankrej cows. In: $27^{\text {th }}$ International Summit on Advancing Veterinary Medical Care: Challenges and Stratagies, Indian Society for Veterinary Medicine. $19^{\text {th }}$ to $21^{\text {st }}$ February, Chennai, India, pp. 9.

Ndahetuye, J.B., Persson, Y., Nyman, A., Tukei, M., Ongol, M.P. and Bage, M. 2019. Etiology and prevalence of subclinical mastitis in dairy herds in peri-urban areas of Kigali in Rwanda. Trop. Anim. Health Prod., 51: 2037-2044.

Ogola, H., Shitandi, A. and Nanua, J. 2007. Effect of mastitis on raw milk compositional quality. J. Vet. Sci., 8(3): 237-242.

Pal, B. and Verma, B.B. 1991. A note on the incidence of subclinical mastitis in cows and buffaloes in an organized farm at Ranchi. Ind. J. Vet. Med., 11: 32-33.

Panchal, I., Sawhney, I.K. and Dang, A.K. 2016. Relation between electrical conductivity, dielectric constant, somatic cell count and some other milk quality parameters in diagnosis of sub-clinical mastitis in Murrah buffaloes. Indian J. Dairy Sci., 69(3): 267-271.

Patel, Y.G. and Trivedi, M.M. 2015. Quarter-wise prevalence of sub-clinical mastitis in crossbred cows. Biosci. Trends, 8: 4727-4729.

Qadri, K. 2015. Efficacy of ceftiofur in the treatment of subclinical and clinical mastitis in cattle. M.V.Sc \& A.H. thesis (Veterinary Medicine), Nanaji Deshmukh Veterinary Science University, Jabalpur.

Quinn, P.J., Carter, M.E., Markey, B.K. and Carter, G.R. 2002. Clinical Veterinary microbiology. Harcourt publishers, Virginia, pp. 331-344.

Rasool, G., Jabbar, M.A., Kazmi, S.E. and Ahmed, A. 1985. Incidence of sub-clinical mastitis in Nilli-Ravi buffaloes and Sahiwal cows. Pak. Vet. J., 5: 76-78.

Schalm, O.W., Carroll, E.J. and Jain, N.C. 1971. Bovine Mastitis. Lea and Febiger, Philadelphia, USA.

Shaikh, S.R., Digraskar, S.U., Siddiqui, M.F., Borikar, S.T., Rajurkar, S.R. and Suryawanshi, P.R. 2019. Epidemiological studies of mastitis in cows reared under different managemental system in and around Parbhani. J. Pharm. Innov., 8(2): 01-05.
Sharma, H., Maiti S.K. and Sharma, K.K. 2007. Prevalence, etiology and antibiogram of microorganisms associated with sub-clinical mastitis in buffaloes in Durg, Chhattisgarh state (India). Int. J. Dairy Sci., 2: 145-151

Sharma, N. and Maiti, S.K. 2010. Incidence, etiology and antibiogram of sub-clinical mastitis in cows in Durg, Chhattisgarh. Indian J. Vet. Res., 19: 45-54.

Sharma, N. and Pandey, V. 2011. Comparative evaluation of three tests used for the screening of mastitis. Indian J. Anim Sci., 81(2): 140-142.

Sharma, N., Maiti, S.K. and Pandey, V. 2008. Sensitivity of indirect tests in the detection of sub-clinical mastitis in buffaloes. Vet. Pract., 9(1): 29-31.

Sharma, N., Singh, N.K., Singh, O.P., Pandey V. and Verma, P.K. 2011. Oxidative stress and antioxidant status during transition period in dairy cow. Asian-Aust. J. Anim. Sci., 24: 479-484.

Sharma, N., Singh, S.G., Huma, Z.I., Sharma, S., Misri, J., Gupta S.K. and Hussain, K. 2018. Mastitis occurrence pattern in dairy cows and importance of related risk factors in the occurrence of mastitis. J. Anim. Res., 8(2): 315-326.

Siddique, N.U., Tripura, T.K., Islam, M.T., Bhuiyan, S.A., Rahman, A.K.M.A. and Bhuiyan, A.K.F.H. 2013. Prevalence of sub-clinical mastitis in high yielding crossbred cows using Draminski mastitis detector. Bangladesh J. Vet. Med., 11: 3741.

Singh, B., Rao, M.L.V., Gupta, D.K., Jain, N.K. and Shukla, P.C. 2010. Epidemiological studies of sub-clinical mastitis in different organized dairy farms. J.N.K.V.V. Res. J., 44: 221222.

Sinha, B., Rahman, S., Hannan, M.A., Rahman, M.M., Bhuiyan, M.U. and Bar, F.Y. 2011. Prevalence of mastitis in dairy cows in selected areas of Bangladesh. Int. J. Bio. Res., 1: 5-9.

Srinivasan, P., Jagadeswaran, D., Manoharan, R., Giri, T., Balasubramaniam, G.A. and Balachandran, P. 2013. Prevalence and etiology of sub-clinical mastitis among buffaloes (Bubalus bubalus) in Namakkal, India. Pak. J. Biol. Sci., 16: 1761-1780.

Swami, S.V., Patil, R.A. and Gadekar, S.D. 2017. Studies on prevalence of sub-clinical mastitis in dairy animals. $J$. Entomol. Zool. Stud., 5(4): 1297-1300.

Tiwari, J.G., Choudhary, S.P. and Tiwari, H.K. 2008. Studies on the incidence of mastitis in relation to stage and number of lactation. Indian Vet. J., 85(11): 1232.

Tufani, N.A., Makhdoomi, D.M. and Hafiz, A. 2012. Epidemiology and therapeutic management of bovine mastitis. Indian J. Anim. Res., 46(2): 148-151. 
